\title{
Prenatal and postnatal tobacco smoke exposure and respiratory health in Russian children
}

\author{
Jouni JK Jaakkola*1, Anna A Kosheleva ${ }^{2}$, Boris A Katsnelson ${ }^{3}$, \\ Sergey V Kuzmin ${ }^{3}$, Larissa I Privalova ${ }^{3}$ and John D Spengler ${ }^{2}$
}

\author{
Address: ${ }^{1}$ Institute of Occupational and Environmental Medicine, University of Birmingham, Birmingham, UK, ${ }^{2}$ Department of Environmental \\ Health, Harvard School of Public Health, Boston MA, USA and ${ }^{3}$ The Urals Regional Center for Environmental Epidemiology (URCEE), \\ Ekaterinburg, Russia \\ Email: Jouni JK Jaakkola* - j.jaakkola@bham.ac.uk; Anna A Kosheleva - akoshele@hsph.harvard.edu; \\ Boris A Katsnelson - bkaznelson@ymrc.ru; Sergey V Kuzmin - SergeyK@urcee.ru; Larissa I Privalova - privalova@ymrc.ru; \\ John D Spengler - spengler@hsph.harvard.edu \\ * Corresponding author
}

Published: 28 March 2006

Respiratory Research 2006, 7:48 doi:10.1 186/1465-9921-7-48

This article is available from: http://respiratory-research.com/content/7/l/48

(C) 2006 Jaakkola et al; licensee BioMed Central Ltd.

This is an Open Access article distributed under the terms of the Creative Commons Attribution License (http://creativecommons.org/licenses/by/2.0), which permits unrestricted use, distribution, and reproduction in any medium, provided the original work is properly cited.
Received: 17 November 2005

Accepted: 28 March 2006

\begin{abstract}
Background: Only few studies have assessed the relative impact of prenatal and postnatal exposure to tobacco smoke on the child's later asthma or chronic respiratory symptoms and to our knowledge no studies have elaborated respiratory infections and allergies in this context.
\end{abstract}

Objective: To assess the effects of prenatal and postnatal exposure to tobacco smoke on respiratory health of Russian school children.

Methods: We studied a population of 595 I children ( 8 to 2 years old) from 9 Russian cities, whose parents answered a questionnaire on their children's respiratory health, home environment, and housing characteristics. The main health outcomes were asthma, allergies, chronic respiratory symptoms, chronic bronchitis, and upper respiratory infections. We used adjusted odds ratios (ORs) from logistic regression analyses as measures of effect.

Results: Prenatal exposure due to maternal smoking had the strongest effects on asthma (adjusted OR 2.46, 95\% Cl I.19-5.08), chronic bronchitis (adjusted OR I.45, 95\% Cl I.08-I.96) and respiratory symptoms, such as wheezing (adjusted OR I.30, 95\% Cl 0.90-1.89). The associations were weaker for exposure during early-life (adjusted ORs I.38/I.27/I.I5 respectively) and after 2 years of age (adjusted ORs I.45/I.34/I.18) compared to prenatal exposure and the weakest or non-existent for current exposure (adjusted ORs I.05/I.09/I.06). Upper respiratory infections were associated more strongly with early-life exposure (adjusted OR I.25, 95\% Cl I.09-I.42) than with prenatal (adjusted OR $0.74,95 \% \mathrm{Cl} 0.54-\mathrm{I} .0 \mathrm{I}$ ) or current exposure (adjusted ORI.05, 95\% $\mathrm{Cl} 0.92-1.20)$. The risk of allergies was also related to early life exposure to tobacco smoke (adjusted OR I.26, 95\% Cl I.13-I.42).

Conclusion: Adverse effects of tobacco smoke on asthma, chronic bronchitis, and chronic respiratory symptoms are strongest when smoking takes place during pregnancy. The relations are weaker for exposure during early-life and after 2 years of age and weakest or non-existent for current exposure. 


\section{Background}

There is strong evidence that maternal smoking during pregnancy is harmful to fetal development. Tobacco smoke constituents pass placenta and reduce intrauterine fetal growth and increases the risk of preterm delivery [1]. There is also accumulating evidence that maternal smoking in pregnancy may influence the fetal development of respiratory system, suggested by findings of a relation between maternal smoking in pregnancy and lung function impairment in newborns [2-7]. Based on a recent review, there is strong evidence that exposure to environmental tobacco smoke (ETS) in childhood causes chronic respiratory symptoms, such as cough, phlegm, and wheezing, susceptibility to lower respiratory infections and to acute and recurrent otitis media, and that it has a causal role in childhood asthma [8]. Evidence of the effects of ETS exposure on allergies is inconsistent [8]. There is also evidence that maternal smoking in pregnancy increase the risk of asthma [8-11] and wheezing [11,12] in childhood. Only few studies have assessed the relative impact of prenatal and postnatal exposure to tobacco smoke on the child's later asthma or chronic respiratory symptoms $[10,12]$, and to our knowledge no studies have elaborated respiratory infections and allergies in this context.

We assessed the independent and joint effects of prenatal and postnatal exposure to tobacco smoke on the risk of asthma and other respiratory problems at school age in a study of Russian school children in 9 cities. We also elaborated whether the effect of smoking in pregnancy on respiratory problems is mainly mediated through reduced fetal growth and duration of pregnancy.

\section{Methods}

\section{Study design and population}

We conducted a cross-sectional study, which was designed to assess the effects of air pollution on children's respiratory health. The study population was recruited through primary schools located in the vicinity of air pollution monitoring stations in 12 areas in 9 Russian cities in the Middle Urals and Upper Volga regions [13]. One school from each area was selected. The study population comprised $59512-5^{\text {th }}$ graders aged 8 to 12 years. The response rate in schools varied from $96 \%$ to $98 \%$. The questionnaire, modified from previous European and North American questionnaires for the Russian conditions [14-16], inquired about the child's personal characteristics, health information, and socioeconomic factors. Local elementary school teachers were trained to instruct the parents about filling out the questionnaires, and parents and guardians were invited to meetings after the school day. After signing an informed consent, a parent completed the questionnaire.

\section{Health outcomes}

The main health outcomes were asthma (ever, current), allergies (any, respiratory), chronic respiratory symptoms (wheezing, cough, phlegm), chronic bronchitis (doctor diagnosed ever, current) and upper respiratory infections (any, severe). In addition we constructed a composite variable called "asthma-like symptoms". These are defined in detail in Table 1.

\section{Exposure assessment}

Exposure assessment was based on questionnaire information on maternal smoking during pregnancy (prenatal exposure), exposure to tobacco smoke during the first two years of life (early-life exposure), after the age of 2, and at the time of the survey (current exposure). Table 2 shows the definitions of the exposure parameters and the prevalences of exposure in the study population.

\section{Statistical methods}

We estimated the prevalences (\%) of the respiratory outcomes and exposure with $95 \%$ confidence intervals based on the binomial distribution. Odds ratio was the measure of effect. We used logistic regression analysis to estimate adjusted odds ratios for the relations between exposure to tobacco smoke, and pregnancy and respiratory outcomes. The basic adjustment was made using the following core covariates: study area, age, gender, mother's education (low, medium, high), and parental asthma. We fitted also income, furry pets and sharing a bedroom as covariates, but excluded them if they changed the studied estimates less than $10 \%$. Additional adjustment was made for low birth weight and preterm delivery when studying the relations between maternal smoking and respiratory outcomes. Maternal smoking was included as an additional covariate when studying the relations of low birth weight and preterm delivery to respiratory outcomes.

\section{Results}

\section{Study population}

Table 3 describes the characteristic of the study population according to exposure to tobacco smoke. The age and sex distributions were similar among the exposed and the reference group, but the exposed were more likely to have mother with low education, to be born prematurely, have lower birth weight, and to be exposed to furry or feathery pets.

\section{Maternal smoking in pregnancy and the risk of adverse pregnancy outcomes}

Only $4.3 \%$ of the mothers reported having smoked during pregnancy. Maternal smoking was a determinant of both preterm delivery and low birth weight. The risk of low birth weight was higher among newborns of smoking women compared to those of non-smokers with an adjusted odds ratio of 1.34 (95\% CI $0.82-2.18)$. The cor- 
Table I: Prevalence of the respiratory health outcomes in the study population. The $95 \%$ confidence intervals are based on binomial distribution.

\begin{tabular}{|c|c|c|}
\hline Health outcome & Definition & Prevalence $(95 \% \mathrm{Cl})$ \\
\hline \multicolumn{3}{|l|}{ Doctor diagnosed asthma } \\
\hline Ever & Ever told by doctor that the child has asthma & $\begin{array}{c}1.9 \\
(1.5-2.3)\end{array}$ \\
\hline Current & $\begin{array}{l}\text { Diagnosed by doctor with shortness of breath, wheeze, or use of asthma } \\
\text { medication within past } 12 \text { months }\end{array}$ & $(1.2-1.8)$ \\
\hline Asthma like symptoms & $\begin{array}{l}\text { Asthma symptoms or asthma medication use, awakening by asthma, wheezing } \\
\text { upon exercise, or hospital care for wheezing within past } 12 \text { months }\end{array}$ & $\begin{array}{c}10.3 \\
(9.5-11.1)\end{array}$ \\
\hline \multicolumn{3}{|l|}{ Wheezing } \\
\hline Ever without cold & Wheezing heard from distance without a cold & $\begin{array}{c}3.1 \\
(2.6-3.5)\end{array}$ \\
\hline Current & $\begin{array}{l}\text { Wheezing heard from distance with or without a cold, shortness of breath with } \\
\text { wheezing, awakening at night by wheezing, wheezing with exercise, or use of } \\
\text { medication or hospitalisation within past } 12 \text { months for wheezing }\end{array}$ & $\begin{array}{c}13.4 \\
(12.5-14.3)\end{array}$ \\
\hline \multicolumn{3}{|c|}{ 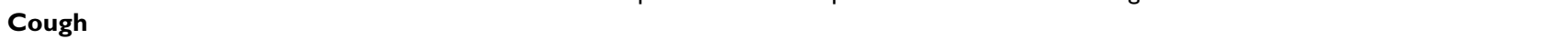 } \\
\hline Any ever & Usual cough day or night & $\begin{array}{c}25.7 \\
(24.6-26.9)\end{array}$ \\
\hline Any persistent & Cough $\geq 3$ consecutive months within past 12 months & $\begin{array}{c}5.5 \\
(4.9-6.1)\end{array}$ \\
\hline \multicolumn{3}{|l|}{ Phlegm } \\
\hline Ever & Wet cough or phlegm produced without a cold & $\begin{array}{c}7.0 \\
(6.3-7.7)\end{array}$ \\
\hline Persistent & Wet cough or phlegm $\geq 3$ consecutive months within past 12 months & $\begin{array}{c}1.5 \\
(1.2-1.9)\end{array}$ \\
\hline Doctor diagnosed bronchitis ever & Ever told by doctor that child has bronchitis & $\begin{array}{c}25.6 \\
(24.5-26.8)\end{array}$ \\
\hline Current bronchitis & Doctor-diagnosed bronchitis within past 12 months & $(7.6-9.0)$ \\
\hline \multicolumn{3}{|l|}{ Respiratory infections } \\
\hline Upper respiratory infection & Acute upper respiratory infection within past 12 months & $\begin{array}{c}76.9 \\
(75.8-78.0)\end{array}$ \\
\hline Severe upper respiratory infection & Two or more acute upper respiratory infections within past 12 months & $\begin{array}{c}24.2 \\
(23.1-25.3)\end{array}$ \\
\hline \multicolumn{3}{|l|}{ Allergy } \\
\hline Any & Doctor-diagnosed allergy, reported hay fever, or pollenosis & $\begin{array}{c}33.2 \\
(32.0-34.4)\end{array}$ \\
\hline Respiratory & $\begin{array}{l}\text { Hay fever or doctor-diagnosed allergies to airborne substances (e.g., dust, } \\
\text { animals, molds, pollens, air pollution, tobacco smoke) }\end{array}$ & $\begin{array}{c}8.0 \\
(7.3-8.7)\end{array}$ \\
\hline
\end{tabular}

responding effect estimate for preterm delivery was 1.85 (95\% CI 1.30-2.68).

\section{Fetal growth, preterm delivery and the risk of respiratory outcomes}

Both preterm delivery and low birth weight increased the risk of asthma and asthma-like symptoms, chronic respiratory symptoms, and doctor-diagnosed bronchitis, as shown in Table 4 . The risk of severe upper respiratory infections was related to preterm delivery (adjusted OR 1.21, 95\% CI 0.99-1.48), but not to low birth weight (adjusted OR 1.01, 95\% CI 0.79-1.30). The risk of allergies was not related to preterm delivery, but interestingly the risk of any allergy was significantly lower among children with low birth weight (adjusted OR 0.78, 95\% CI 0.61-0.99).

\section{Prenatal and postnatal exposure and the risk of respiratory outcomes}

Table 5 shows the relations between prenatal, early-life, after 2 years of age, and current exposures and the risk of various health outcomes. The effect estimates are displayed adjusted for the core covariates and further for preterm delivery and low birth weight.

Maternal smoking during pregnancy had a strong consistent effect on the risk of doctor-diagnosed asthma (ever: adjusted OR 2.46, 95\% CI 1.19-5.08), asthma-like symptoms (adjusted OR 1.39 95\% CI 0.93-2.08), current wheezing (adjusted OR 1.30, 95\% CI 0.90-1.89), cough (adjusted OR 1.54, 95\% CI 1.14-2.08) and doctor diagnosed bronchitis (ever: adjusted OR 1.45, 95\% CI 1.081.96). The occurrence of phlegm, upper respiratory infec- 
Table 2: Exposure to tobacco smoke in Russian school children $(\mathbf{N}=597 \mathrm{I})$.

\begin{tabular}{|c|c|c|}
\hline Exposure & Definition & Prevalence $(95 \% \mathrm{CI})$ \\
\hline $\begin{array}{l}\text { Fetal exposure: Mother smoked } \\
\text { during pregnancy }\end{array}$ & $\begin{array}{l}\text { Did this child's mother smoke while she was pregnant with this child? If yes: (A) } \\
\text { Specify in figures number of cigarettes per week if she was an occasional smoker. } \\
\text { (B) Specify in figures number of cigarettes per day if she smoked every day. }\end{array}$ & $\begin{array}{c}4.3 \\
(3.8-4.9)\end{array}$ \\
\hline $\begin{array}{l}\text { Early-life exposure: ETS when child } \\
\text { was younger that } 2 \text { years }\end{array}$ & $\begin{array}{l}\text { Between the times this child was born and he or she turned } 2 \text { years old, were } \\
\text { there any smokers in regular contact with the child? Include regular visitors, for } \\
\text { example, grandparents or baby-sitters. If yes: Did this child's mother (or } \\
\text { stepmother or other female taking care of the child) smoke during this period? }\end{array}$ & $\begin{array}{c}46.5 \\
(45.2-47.7)\end{array}$ \\
\hline ETS when child after 2 years of age & $\begin{array}{l}\text { Between the times the child turned } 2 \text { years old and he or she started school, were } \\
\text { there any smokers in regular contact with the child? Include regular visitors, for } \\
\text { example, grandparents or baby-sitters. If yes: Did this child's mother (or } \\
\text { stepmother or other female taking care of the child) smoke during this period? }\end{array}$ & $\begin{array}{c}51.1 \\
(49.8-52.4)\end{array}$ \\
\hline Current smokers in the household & $\begin{array}{l}\text { Does anyone daily smoke cigarettes, papirosy (Russian non-filter cigarette), cigars, } \\
\text { or pipes in this child's home? If yes: (A) On average, how many cigarettes or } \\
\text { papirosy, in total, are smoked in the home each day when the child is at home? (B) } \\
\text { On average, how many cigars are smoked in the home each day while the child is } \\
\text { at home? (C) On average, how many pipes are smoked in the home each day while } \\
\text { the child is at home? }\end{array}$ & $\begin{array}{c}46.1 \\
(44.9-47.4)\end{array}$ \\
\hline Prenatal exposure only & & $\begin{array}{c}0.2 \\
(0.1-0.3)\end{array}$ \\
\hline Postnatal exposure only & & $\begin{array}{c}59.8 \\
(58.6-6 I .1)\end{array}$ \\
\hline $\begin{array}{l}\text { Both prenatal and postnatal } \\
\text { exposure }\end{array}$ & & $\begin{array}{c}4.1 \\
(3.6-4.7)\end{array}$ \\
\hline Any tobacco smoke exposure & Any of the above. & $\begin{array}{c}64.5 \\
(63.3-65.7)\end{array}$ \\
\hline
\end{tabular}

tions and allergy were not related to maternal smoking in pregnancy.

The effect estimates of early-life exposure for asthma and asthma like symptoms were lower than corresponding estimates for maternal smoking in pregnancy, varying from 1.04 to 1.38 . The effect estimates of current asthma (adjusted OR 1.35, 95\% CI 0.86-2.15), asthma ever (adjusted OR 1.38, 95\% CI 0.93-2.06) and current wheezing (adjusted OR 1.15, 95\% CI 1.01-1.38) were elevated, although not reaching statistical significance. That of asthma-like symptoms (adjusted OR 1.26, 95\% CI 1.05-1.51) was statistically significant. Adjustment for preterm delivery and low birth weight did not alter the effect estimates. The risk of cough (ever: adjusted OR 1.34, 95\% CI 1.18-1.52), doctor diagnosed bronchitis (adjusted OR 1.27, 95\% CI 1.12-1.44), upper respiratory infections (adjusted OR 1.25, 95\% CI 1.09-1.42) as well as allergies (any: adjusted OR 1.26, 95\% CI 1.13-1.42; respiratory: adjusted OR $1.20,95 \%$ CI $0.99-1.47)$ were also related to early-life exposure to ETS. The effect estimates for exposure after 2 years of age were similar to those of early-life exposure.

The risk of asthma, asthma like symptoms, wheezing, and upper respiratory infections were not related to current exposure to ETS, but the effect estimates for cough (any adjusted OR 1.33, 95\% CI 1.17-1.51) and doctor diagnosed bronchitis (adjusted OR 1.09, 95\% CI 0.96-1.24) as well as any allergy (adjusted OR 1.11, 95\% CI 0.991.25 ) were elevated.

Table 6 compares the effects of prenatal exposure only, postnatal exposure only and both prenatal and postnatal exposure. In general the effect of experiencing both prenatal and postnatal exposure was stronger than the effect of postnatal exposure only. There were only 10 individuals who were exposed only during pregnancy and therefore the estimates are either not available or with wide confidence intervals. Therefore the comparison of independent effects of prenatal and postnatal exposures was possible for only few outcomes. The effects of prenatal exposure appeared to be stronger for asthma like symptoms and bronchitis.

\section{Discussion}

Our population-based epidemiologic study in nine Russian cities shows the harmful effects of fetal and early-life exposure to tobacco smoke products. Prenatal exposure due to maternal smoking had the strongest effects on asthma, chronic bronchitis and respiratory symptoms. The associations were weaker for exposure during earlylife and after 2 years of age and weakest or non-existent for current exposure. Upper respiratory infections were associated more strongly with early-life exposure than with prenatal exposure. The risk of allergies was also weakly related to both prenatal and postnatal exposure to tobacco smoke. 
Table 3: Characteristics of the study population by exposure to tobacco products, either through maternal smoking in pregnancy or environmental tobacco smoke in lifetime.

\begin{tabular}{|c|c|c|c|}
\hline Characteristic & Exposed, N (\%) & Reference, N (\%) & Total, N(\%) \\
\hline Total & $3790(64.5)$ & $2084(35.5)$ & 5874 \\
\hline \multicolumn{4}{|l|}{ Age } \\
\hline 8 & $56 \mid(14.8)$ & $317(15.2)$ & $878(14.9)$ \\
\hline 9 & $1268(33.5)$ & $675(32.4)$ & $1943(33.1)$ \\
\hline 10 & $1216(32.1)$ & $654(31.4)$ & $1870(31.8)$ \\
\hline 11 & $647(17.1)$ & $396(19.0)$ & $1043(17.8)$ \\
\hline 12 & $98(2.6)$ & $42(2.0)$ & $140(2.4)$ \\
\hline Gender, boy & $1918(50.6)$ & $1053(50.5)$ & $297 \mid(50.6)$ \\
\hline \multicolumn{4}{|l|}{ Mother's education } \\
\hline Higher & $636(16.9)$ & 492 (23.7) & 1128 (19.3) \\
\hline Incomplete higher or college & $2070(55.0)$ & $1102(53.2)$ & $3172(54.4)$ \\
\hline Secondary & $1056(28.1)$ & $479(23.1)$ & $1535(26.3)$ \\
\hline Parental asthma & $66(1.8)$ & $41(2.0)$ & $107(1.8)$ \\
\hline Low birth weight ( $\leq 2500 \mathrm{~g}$ ) & $248(6.9)$ & $109(5.5)$ & $357(6.4)$ \\
\hline Premature birth ( $<37$ weeks) & $390(10.5)$ & $172(8.3)$ & $562(9.7)$ \\
\hline Income below average & $2404(63.9)$ & $1259(60.8)$ & $3663(62.8)$ \\
\hline Others sleeping in the same room with child & $2760(73.5)$ & $1490(71.9)$ & 4250 (72.9) \\
\hline Furry or feathery pets & $2421(65.6)$ & $1247(61.4)$ & $3668(64.1)$ \\
\hline
\end{tabular}

Although maternal smoking was, as expected, a strong determinant of preterm delivery and low birth weight, and these adverse pregnancy outcomes were strong predictors of asthma and other respiratory problems, adjustment for preterm delivery and low birth weight had little influence on the associations between prenatal tobacco smoke exposure and respiratory outcomes.

\section{Validity of results}

We achieved a very high response rate due to strong support by the parents and teachers and this practically eliminates selection bias related to participation. Information on exposure to tobacco smoke was collected retrospectively and there is a possibility for both random and systematic errors. Maternal smoking during pregnancy was reported to be much lower (4\%) compared to maternal smoking after the delivery ( $12 \%)$. This could reflect problems in recall or cultural behavior to quit smoking during pregnancy. The latter alternative is supported by our similar findings in another Russian female population in Karelia, North-West Russia (J Jaakkola, unpublished observation), where smoking during pregnancy was 5\% whereas the smoking was $25 \%$ when the child was at school. Observed associations between maternal smoking and low birth weight, which are consistent with previously published meta-analyses [1] and research reports [9], support the validity of information on prenatal exposure indirectly. Given the nature of the study design we can not fully exclude the possibility of non-comparable exposure information from parents of ill and healthy children. We were able to adjust the effect estimates for several potential confounders.

\section{Synthesis with previous knowledge}

Only few previous studies have elaborated the relative contributions of prenatal and postnatal exposures to ETS on asthma $[10,11]$, and chronic respiratory symptoms $[11,12]$, and to our knowledge no studies have focused on respiratory infections or allergies.

Our findings on the stronger effect of prenatal exposure on asthma and wheezing compared with postnatal exposure are consistent with the results of a cross-sectional study of 11,5008 to 11 years old children in 24 US and Canadian communities [11]. A recent cross-sectional study of 5762 Californian school children [10] also provided evidence of the relative importance of prenatal exposure in development of asthma with a retrospective recording of in utero and previous postnatal and current exposure. In utero exposure to maternal smoking without subsequent postnatal exposure to ETS was related to the presence of asthma in $4^{\text {th }}, 7^{\text {th }}$, and $10^{\text {th }}$ grade children with an adjusted odds ratio of 1.8 (95\% CI $1.1-2.9)$. In contrast, current or previous postnatal exposure to ETS was not associated with asthma risk, but the risk of lifetime wheezing was increased with an odds ratio of 1.3 (95\% CI $1.1-1.5)$. Lux and colleagues showed in a longitudinal study of 8561 English children that maternal smoking during pregnancy causes wheezing during the first 30 months of life independently from postnatal exposure [11]. A large population-based cohort study of 55,000 Finnish children estimated a 35\% increased risk of asthma by the age of 7 years related to maternal smoking of over 10 cigarettes per day during pregnancy [9]. Similarly to the present study, maternal smoking was a strong determi- 
Table 4: Crude and adjusted odds ratios for respiratory health outcomes according to low birth weight and preterm delivery.

\begin{tabular}{|c|c|c|c|c|}
\hline \multirow[t]{2}{*}{ Health outcome } & \multicolumn{2}{|c|}{ Preterm delivery ( $<37$ weeks) } & \multicolumn{2}{|c|}{ Low birth weight $(<2500 \mathrm{~g})$} \\
\hline & Crude OR $(95 \% \mathrm{CI})$ & Adjusted I OR (95\% CI) & Crude OR (95\% CI) & Adjusted I OR ( $95 \% \mathrm{Cl})$ \\
\hline \multicolumn{5}{|l|}{ Doctor diagnosed asthma } \\
\hline Ever & $\begin{array}{c}1.80 \\
(1.06-3.04)\end{array}$ & $\begin{array}{c}1.96 \\
(1.14-3.35)\end{array}$ & $\begin{array}{c}1.73 \\
(0.92-3.27)\end{array}$ & $\begin{array}{c}1.88 \\
(0.98-3.59)\end{array}$ \\
\hline Current & $\begin{array}{c}1.83 \\
(1.00-3.34)\end{array}$ & $\begin{array}{c}1.95 \\
(1.06-3.62)\end{array}$ & $\begin{array}{c}1.93 \\
(0.95-3.89)\end{array}$ & $\begin{array}{c}2.05 \\
(0.99-4.22)\end{array}$ \\
\hline Asthma like symptoms & $\begin{array}{c}1.47 \\
(1.13-1.90)\end{array}$ & $\begin{array}{c}1.48 \\
(1.14-1.93)\end{array}$ & $\begin{array}{c}1.38 \\
(1.00-1.90)\end{array}$ & $\begin{array}{c}1.43 \\
(1.03-1.99)\end{array}$ \\
\hline \multicolumn{5}{|l|}{ Wheezing } \\
\hline Ever without cold & $\begin{array}{c}1.54 \\
(0.99-2.40)\end{array}$ & $\begin{array}{c}1.62 \\
(1.04-2.54)\end{array}$ & $\begin{array}{c}1.67 \\
(1.00-2.79)\end{array}$ & $\begin{array}{c}1.76 \\
(1.04-2.96)\end{array}$ \\
\hline Current & $\begin{array}{c}1.28 \\
(1.00-1.63)\end{array}$ & $\begin{array}{c}1.30 \\
(1.01-1.66)\end{array}$ & $\begin{array}{c}1.19 \\
(0.88-1.62)\end{array}$ & $\begin{array}{c}1.24 \\
(0.9 \mid-1.69)\end{array}$ \\
\hline \multicolumn{5}{|l|}{ Cough } \\
\hline Ever & $\begin{array}{c}1.38 \\
(1.14-1.67)\end{array}$ & $\begin{array}{c}1.38 \\
(1.13-1.68)\end{array}$ & $\begin{array}{c}1.22 \\
(0.96-1.56)\end{array}$ & $\begin{array}{c}1.27 \\
(0.99-1.62)\end{array}$ \\
\hline Persistent & $\begin{array}{c}1.78 \\
(1.28-2.46)\end{array}$ & $\begin{array}{c}1.86 \\
(1.34-2.59)\end{array}$ & $\begin{array}{c}1.66 \\
(1.12-2.48)\end{array}$ & $\begin{array}{c}1.72 \\
(1.15-2.58)\end{array}$ \\
\hline \multicolumn{5}{|l|}{ Phlegm } \\
\hline Ever & $\begin{array}{c}1.21 \\
(0.87-1.68)\end{array}$ & $\begin{array}{c}1.23 \\
(0.88-1.7 I)\end{array}$ & $\begin{array}{c}1.15 \\
(0.76-1.73)\end{array}$ & $\begin{array}{c}1.18 \\
(0.78-1.78)\end{array}$ \\
\hline Persistent & $\begin{array}{c}2.52 \\
(1.47-4.34)\end{array}$ & $\begin{array}{c}2.73 \\
(1.57-4.76)\end{array}$ & $\begin{array}{c}2.13 \\
(1.09-4.16)\end{array}$ & $\begin{array}{c}2.26 \\
(1.14-4.47)\end{array}$ \\
\hline Doctor diagnosed bronchitis ever & $\begin{array}{c}1.50 \\
(1.24-1.81)\end{array}$ & $\begin{array}{c}1.55 \\
(1.28-1.88)\end{array}$ & $\begin{array}{c}1.53 \\
(1.22-1.93)\end{array}$ & $\begin{array}{c}1.63 \\
(1.29-2.06)\end{array}$ \\
\hline Current bronchitis & $\begin{array}{c}1.49 \\
(1.12-1.97)\end{array}$ & $\begin{array}{c}1.52 \\
(1.14-2.02)\end{array}$ & $\begin{array}{c}1.28 \\
(0.89-1.84)\end{array}$ & $\begin{array}{c}1.32 \\
(0.91-1.92)\end{array}$ \\
\hline \multicolumn{5}{|l|}{ Respiratory infections } \\
\hline Upper respiratory infection & $\begin{array}{c}1.10 \\
(0.89-1.36)\end{array}$ & $\begin{array}{c}1.1 \mathrm{I} \\
(0.89-1.38)\end{array}$ & $\begin{array}{c}1.06 \\
(0.81-1.38)\end{array}$ & $\begin{array}{c}1.06 \\
(0.81-1.39)\end{array}$ \\
\hline Severe upper respiratory infection & $\begin{array}{c}1.22 \\
(1.00-1.48)\end{array}$ & $\begin{array}{c}1.21 \\
(0.99-1.48)\end{array}$ & $\begin{array}{c}1.01 \\
(0.79-1.30)\end{array}$ & $\begin{array}{c}1.0 \mathrm{I} \\
(0.79-1.30)\end{array}$ \\
\hline \multicolumn{5}{|l|}{ Allergy } \\
\hline Any & $\begin{array}{c}I .0 \mathrm{I} \\
(0.84-\mid .2 \mathrm{I})\end{array}$ & $\begin{array}{c}1.04 \\
(0.86-1.26)\end{array}$ & $\begin{array}{c}0.78 \\
(0.62-0.99)\end{array}$ & $\begin{array}{c}0.78 \\
(0.61-0.99)\end{array}$ \\
\hline Respiratory & $\begin{array}{c}1.13 \\
(0.83-1.55)\end{array}$ & $\begin{array}{c}1.14 \\
(0.83-1.57)\end{array}$ & $\begin{array}{c}0.93 \\
(0.62-1.40)\end{array}$ & $\begin{array}{c}0.94 \\
(0.62-I .4 I)\end{array}$ \\
\hline
\end{tabular}

I - Odds ratios adjusted for study area, age, gender, mother's education, parental asthma, maternal smoking during pregnancy.

nant of both preterm delivery and low birth weight, and these adverse pregnancy outcomes were strong predictors of asthma, but practically none of the effect of maternal smoking on asthma was mediated via the pregnancy outcomes.

In the present study prenatal exposure had also a stronger effect on both lifetime and current chronic bronchitis compared with early life exposure and there was no association between current exposure and chronic bronchitis. To our knowledge this has not been reported before. However, the occurrence of upper respiratory infections during the previous year was related to early life exposure to ETS, but not to prenatal or current exposure.

Our results strengthen the evidence that also postnatal exposure to tobacco smoke increases the risk of asthma in childhood. The effect estimates for early-life exposure and exposure after the age of two were consistently elevated suggesting a 30\% increase in risk, although there was no association between current exposure and asthma. The latter could be explained by avoidance of smoking in the presence of the child after the diagnosis of asthma. Unfortunately the number of children with prenatal exposure only was too small to get good estimates of the independent effect of prenatal exposure only. However the effect of both prenatal and postnatal exposure on asthma was much stronger (adjusted OR 3.48) than the effect of postnatal exposure only (adjusted OR 1.32), suggesting a synergistic effect of prenatal and postnatal exposures. There is evidence that maternal smoking in pregnancy reduces the fetal development of lung function [2-7], which may play a role in the susceptibility to the effects of exposure to environmental tobacco smoke after delivery. Maternal 
Table 5: Adjusted odds ratios for respiratory health outcomes according prenatal, early-life and current exposure.

\begin{tabular}{|c|c|c|c|c|c|c|c|c|}
\hline \multirow[t]{2}{*}{ Health outcome } & \multicolumn{2}{|c|}{ Prenatal exposure } & \multicolumn{2}{|c|}{ Early-life exposure } & \multicolumn{2}{|c|}{ Exposure after age of 2} & \multicolumn{2}{|c|}{ Current exposure } \\
\hline & $\begin{array}{c}\text { Adjusted OR } \\
{ }^{\prime}(95 \% \mathrm{CI})\end{array}$ & $\begin{array}{c}\text { Adjusted OR } \\
2 \text { (95\% CI) }\end{array}$ & $\begin{array}{c}\text { Adjusted OR } \\
{ }^{\prime}(95 \% \mathrm{CI})\end{array}$ & $\begin{array}{l}\text { Adjusted OR }{ }^{2} \\
(95 \% \mathrm{CI})\end{array}$ & $\begin{array}{c}\text { Adjusted OR } \\
{ }^{\prime}(95 \% \mathrm{CI})\end{array}$ & $\begin{array}{c}\text { Adjusted OR } \\
2(95 \% \mathrm{Cl})\end{array}$ & $\begin{array}{c}\text { Adjusted OR } \\
{ }^{\prime}(95 \% \mathrm{CI})\end{array}$ & $\begin{array}{l}\text { Adjusted OR } \\
{ }_{2}(95 \% \mathrm{CI})\end{array}$ \\
\hline \multicolumn{9}{|c|}{ Doctor diagnosed asthma } \\
\hline Ever & $\begin{array}{c}2.40 \\
(1.17-4.93)\end{array}$ & $\begin{array}{c}2.46 \\
(1.19-5.08)\end{array}$ & $\begin{array}{c}1.39 \\
(0.94-2.06)\end{array}$ & $\begin{array}{c}1.38 \\
(0.93-2.06)\end{array}$ & $\begin{array}{c}1.45 \\
(0.97-2.17)\end{array}$ & $\begin{array}{c}1.45 \\
(0.96-2.18)\end{array}$ & $\begin{array}{c}1.10 \\
(0.74-1.63)\end{array}$ & $\begin{array}{c}1.05 \\
(0.70-1.58)\end{array}$ \\
\hline Current & $\begin{array}{c}2.55 \\
(1.13-5.78)\end{array}$ & $\begin{array}{c}2.64 \\
(1.16-6.03)\end{array}$ & $\begin{array}{c}1.35 \\
(0.87-2.12)\end{array}$ & $\begin{array}{c}1.36 \\
(0.86-2.15)\end{array}$ & $\begin{array}{c}1.44 \\
(0.9 \mid-2.27)\end{array}$ & $\begin{array}{c}1.44 \\
(0.90-2.32)\end{array}$ & $\begin{array}{c}1.19 \\
(0.75-1.87)\end{array}$ & $\begin{array}{c}1.09 \\
(0.68-1.74)\end{array}$ \\
\hline $\begin{array}{l}\text { Asthma like } \\
\text { symptoms }\end{array}$ & $\begin{array}{c}1.48 \\
(1.01-2.15)\end{array}$ & $\begin{array}{c}1.39 \\
(0.93-2.08)\end{array}$ & $\begin{array}{c}1.28 \\
(1.07-1.52)\end{array}$ & $\begin{array}{c}1.26 \\
(1.05-1.5 \mathrm{I})\end{array}$ & $\begin{array}{c}1.23 \\
(1.03-1.47)\end{array}$ & $\begin{array}{c}1.22 \\
(1.02-1.47)\end{array}$ & $\begin{array}{c}1.09 \\
(0.91-1.30)\end{array}$ & $\begin{array}{c}1.09 \\
(0.90-1.30)\end{array}$ \\
\hline \multicolumn{9}{|l|}{ Wheezing } \\
\hline Ever without cold & $\begin{array}{c}0.74 \\
(0.30-1.83)\end{array}$ & $\begin{array}{c}0.59 \\
(0.21-1.63)\end{array}$ & $\begin{array}{c}1.24 \\
(0.91-1.69)\end{array}$ & $\begin{array}{c}1.24 \\
(0.91-1.70)\end{array}$ & $\begin{array}{c}1.40 \\
(1.02-1.92)\end{array}$ & $\begin{array}{c}1.42 \\
(1.03-1.96)\end{array}$ & $\begin{array}{c}1.00 \\
(0.73-1.38)\end{array}$ & $\begin{array}{c}1.00 \\
(0.72-1.37)\end{array}$ \\
\hline Current & $\begin{array}{c}1.37 \\
(0.97-1.94)\end{array}$ & $\begin{array}{c}1.30 \\
(0.90-1.89)\end{array}$ & $\begin{array}{c}1.18 \\
(1.01-1.38)\end{array}$ & $\begin{array}{c}1.15 \\
(0.98-1.36)\end{array}$ & $\begin{array}{c}1.20 \\
(1.03-1.4 \mid)\end{array}$ & $\begin{array}{c}1.18 \\
(1.00-1.39)\end{array}$ & $\begin{array}{c}1.09 \\
(0.93-1.28)\end{array}$ & $\begin{array}{c}1.06 \\
(0.90-1.25)\end{array}$ \\
\hline \multicolumn{9}{|l|}{ Cough } \\
\hline Ever & $\begin{array}{c}1.51 \\
(1.13-2.02)\end{array}$ & $\begin{array}{c}1.54 \\
(1.14-2.08)\end{array}$ & $\begin{array}{c}1.35 \\
(1.2-1.53)\end{array}$ & $\begin{array}{c}1.34 \\
(1.18-1.52)\end{array}$ & $\begin{array}{c}1.49 \\
(1.31-1.68)\end{array}$ & $\begin{array}{c}1.46 \\
(1.28-1.66)\end{array}$ & $\begin{array}{c}1.33 \\
(1.18-1.51)\end{array}$ & $\begin{array}{c}1.33 \\
(1.17-1.51)\end{array}$ \\
\hline Persistent & $\begin{array}{c}1.11 \\
(0.63-1.95)\end{array}$ & $\begin{array}{c}0.98 \\
(0.53-1.8)\end{array}$ & $\begin{array}{c}1.27 \\
(1.00-1.6)\end{array}$ & $\begin{array}{c}1.20 \\
(0.94-1.53)\end{array}$ & $\begin{array}{c}1.27 \\
(1-1.62)\end{array}$ & $\begin{array}{c}1.23 \\
(0.96-1.58)\end{array}$ & $\begin{array}{c}1.24 \\
(0.98-1.58)\end{array}$ & $\begin{array}{c}1.19 \\
(0.93-1.52)\end{array}$ \\
\hline \multicolumn{9}{|l|}{ Phlegm } \\
\hline Ever & $\begin{array}{c}0.98 \\
(0.58-1.65)\end{array}$ & $\begin{array}{c}0.98 \\
(0.57-1.69)\end{array}$ & $\begin{array}{c}1.15 \\
(0.93-1.4 I)\end{array}$ & $\begin{array}{c}1.15 \\
(0.92-1.42)\end{array}$ & $\begin{array}{c}1.39 \\
(1.13-1.72)\end{array}$ & $\begin{array}{c}1.38 \\
(1.11-\mid .7 I)\end{array}$ & $\begin{array}{c}1.31 \\
(1.06-1.62)\end{array}$ & $\begin{array}{c}1.37 \\
(1.1-1.7)\end{array}$ \\
\hline Persistent & $\begin{array}{c}0.56 \\
(0.14-2.34)\end{array}$ & $\begin{array}{c}0.56 \\
(0.13-2.35)\end{array}$ & $\begin{array}{c}1.33 \\
(0.85-2.07)\end{array}$ & $\begin{array}{c}1.33 \\
(0.84-2.11)\end{array}$ & $\begin{array}{c}1.68 \\
(1.05-2.68)\end{array}$ & $\begin{array}{c}1.74 \\
(1.07-2.84)\end{array}$ & $\begin{array}{c}0.82 \\
(0.52-1.31)\end{array}$ & $\begin{array}{c}0.84 \\
(0.52-1.35)\end{array}$ \\
\hline $\begin{array}{l}\text { Doctor-diag } \\
\text { bronchitis ever }\end{array}$ & $\begin{array}{c}1.4 \mid \\
(1.06-1.88)\end{array}$ & $\begin{array}{c}1.45 \\
(1.08-1.96)\end{array}$ & $\begin{array}{c}1.28 \\
(1.14-1.45)\end{array}$ & $\begin{array}{c}1.27 \\
(1.12-1.44)\end{array}$ & $\begin{array}{c}1.33 \\
(1.18-1.51)\end{array}$ & $\begin{array}{c}1.34 \\
(1.18-1.52)\end{array}$ & $\begin{array}{c}1.12 \\
(0.99-1.26)\end{array}$ & $\begin{array}{c}1.09 \\
(0.96-1.24)\end{array}$ \\
\hline $\begin{array}{l}\text { Current } \\
\text { bronchitis }\end{array}$ & $\begin{array}{c}1.71 \\
(1.14-2.56)\end{array}$ & $\begin{array}{c}1.63 \\
(1.06-2.49)\end{array}$ & $\begin{array}{c}1.06 \\
(0.87-1.28)\end{array}$ & $\begin{array}{c}1.04 \\
(0.85-1.27)\end{array}$ & $\begin{array}{c}1.11 \\
(0.92-1.34)\end{array}$ & $\begin{array}{c}1.10 \\
(0.90-1.34)\end{array}$ & $\begin{array}{c}1.01 \\
(0.83-1.22)\end{array}$ & $\begin{array}{c}0.96 \\
(0.79-1.18)\end{array}$ \\
\hline \multicolumn{9}{|c|}{ Respiratory infections } \\
\hline $\begin{array}{l}\text { Upper respiratory } \\
\text { infection }\end{array}$ & $\begin{array}{c}0.77 \\
(0.57-1.03)\end{array}$ & $\begin{array}{c}0.74 \\
(0.54-1.01)\end{array}$ & $\begin{array}{c}1.25 \\
(1.10-1.41)\end{array}$ & $\begin{array}{c}1.25 \\
(1.09-1.42)\end{array}$ & $\begin{array}{c}1.28 \\
(1.13-1.45)\end{array}$ & $\begin{array}{c}1.29 \\
(1.12-1.47)\end{array}$ & $\begin{array}{c}1.04 \\
(0.92-1.18)\end{array}$ & $\begin{array}{c}1.05 \\
(0.92-1.20)\end{array}$ \\
\hline $\begin{array}{l}\text { Severe upper } \\
\text { respiratory infection }\end{array}$ & $\begin{array}{c}1.21 \\
(0.90-1.63)\end{array}$ & $\begin{array}{c}1.14 \\
(0.83-1.56)\end{array}$ & $\begin{array}{c}1.24 \\
(1.10-1.40)\end{array}$ & $\begin{array}{c}1.23 \\
(1.09-1.40)\end{array}$ & $\begin{array}{c}1.18 \\
(1.04-1.33)\end{array}$ & $\begin{array}{c}1.18 \\
(1.04-1.34)\end{array}$ & $\begin{array}{c}1.04 \\
(0.92-1.17)\end{array}$ & $\begin{array}{c}1.05 \\
(0.93-1.19)\end{array}$ \\
\hline \multicolumn{9}{|l|}{ Allergy } \\
\hline Any & $\begin{array}{c}0.98 \\
(0.74-\mid .31)\end{array}$ & $\begin{array}{c}1.00 \\
(0.74-1.35)\end{array}$ & $\begin{array}{c}1.30 \\
(1.16-1.46)\end{array}$ & $\begin{array}{c}1.26 \\
(1.13-1.42)\end{array}$ & $\begin{array}{c}1.20 \\
(1.07-1.35)\end{array}$ & $\begin{array}{c}1.18 \\
(1.05-1.33)\end{array}$ & $\begin{array}{c}1.12 \\
(1-1.25)\end{array}$ & $\begin{array}{c}1.11 \\
(0.99-1.25)\end{array}$ \\
\hline Respiratory & $\begin{array}{c}1.14 \\
(0.70-1.85)\end{array}$ & $\begin{array}{c}1.13 \\
(0.68-1.87)\end{array}$ & $\begin{array}{c}1.24 \\
(1.02-1.51)\end{array}$ & $\begin{array}{c}1.20 \\
(0.99-1.47)\end{array}$ & $\begin{array}{c}1.10 \\
(0.90-1.34)\end{array}$ & $\begin{array}{c}1.09 \\
(0.89-1.33)\end{array}$ & $\begin{array}{c}1.05 \\
(0.86-1.28)\end{array}$ & $\begin{array}{c}1.05 \\
(0.86-1.29)\end{array}$ \\
\hline
\end{tabular}

I Logistic regression analysis: adjusted for the core covariates including study area, age, gender, mother's education, and parental asthma.

2 Logistic regression analysis: adjusted for the core covariates, preterm delivery and low birth weight.

smoking in pregnancy may also have other effects increasing the susceptibility, including effects on development and maturation of the pulmonary immune system [17] leading to an increased bronchial reactivity in early childhood as shown by Young and colleagues [7].

Early life exposure to ETS was a determinant of both any and respiratory allergy at school age. There was a weak non-significant association between prenatal exposure and respiratory allergy and no association with any allergy. There was also a weak positive association between current exposure and risk of any allergy. In their systematic review based on 36 relevant articles in 1998, Strachan and Cook [18] concluded that parental smoking, either before or immediately after birth, is unlikely to increase the risk of allergic sensitisation in children. In a Norwegian study, a negative association between prenatal smoking and childhood atopy was found, but rather than proposing a causal relation the investigators suggest that selective avoidance of smoking during pregnancy is an alternative explanation [19].

\section{Concluding remarks}

This large epidemiologic study in Russian children confirms that smoking during pregnancy and in the presence of children is harmful for respiratory health increasing the risk of asthma, chronic bronchitis, and respiratory infections and possibly allergies. The results strengthen the evidence that the adverse effects of tobacco smoke on asthma, chronic bronchitis, and chronic respiratory symptoms are strongest when smoking takes place during pregnancy and stronger during early life compared with exposure in school age. Although maternal smoking reduces duration of gestation and fetal growth and these pregnancy outcomes predict respiratory illness, little of the effect of maternal smoking in pregnancy on respiratory health is mediated via preterm delivery and low birth weight. In conclusion, smoking in pregnancy and in the presence of children is among the most serious preventable hazards to children's health.

\section{Authors' contributions}

JJ conceived the hypothesis, participated in the planning of the study and statistical analyses, and wrote the paper. 
Table 6: Adjusted odds ratios for respiratory health outcomes according prenatal exposure only $(n=I 0)$, postnatal exposure only $(n=$ $3491)$ and both prenatal and postnatal exposure $(n=242)$.

\begin{tabular}{|c|c|c|c|}
\hline Health outcome & $\begin{array}{l}\text { Prenatal exposure only } \\
\text { Adjusted OR ' }(95 \% \mathrm{Cl})\end{array}$ & $\begin{array}{l}\text { Postnatal exposure only } \\
\text { Adjusted OR }{ }^{\prime}(95 \% \mathrm{CI})\end{array}$ & $\begin{array}{l}\text { Both prenatal and postnatal } \\
\text { exposure Adjusted OR }(95 \% \mathrm{Cl})\end{array}$ \\
\hline \multicolumn{4}{|l|}{ Doctor diagnosed asthma } \\
\hline Ever & $\mathrm{NA}^{2}$ & $1.20(0.77-1.87)$ & $2.96(1.35-6.5 I)$ \\
\hline Current & NA 2 & $1.32(0.79-2.23)$ & $3.48(I .4 I-8.56)$ \\
\hline $\begin{array}{l}\text { Asthma like symptoms } \\
\text { Wheezing }\end{array}$ & $1.53(0.18-12.77)$ & $1.26(1.03-1.54)$ & $1.64(1.07-2.53)$ \\
\hline Ever without cold & NA 2 & $1.32(0.94-1.86)$ & $0.75(0.27-2.13)$ \\
\hline Current & $1.07(0.13-8.91)$ & $1.21(1.02-1.45)$ & $1.51(1.01-2.24)$ \\
\hline \multicolumn{4}{|l|}{ Cough } \\
\hline Ever & $1.39(0.28-7.00)$ & $1.42(1.23-1.63)$ & $1.96(1.42-2.70)$ \\
\hline Persistent & NA 2 & $1.30(0.99-1.70)$ & $1.19(0.63-2.25)$ \\
\hline \multicolumn{4}{|l|}{ Phlegm } \\
\hline Ever & NA 2 & $1.37(1.08-1.74)$ & $1.25(0.70-2.21)$ \\
\hline Persistent & NA 2 & $1.53(0.90-2.59)$ & $0.77(0.17-3.39)$ \\
\hline $\begin{array}{l}\text { Doctor diagnosed bronchitis } \\
\text { ever }\end{array}$ & $3.50(0.84-14.52)$ & $1.34(1.17-1.54)$ & $1.75(1.27-2.40)$ \\
\hline Current bronchitis & $1.64(0.18-14.58)$ & $1.16(0.93-1.43)$ & $1.81(1.15-2.87)$ \\
\hline \multicolumn{4}{|l|}{ Respiratory infections } \\
\hline Upper respiratory infection & $0.47(0.11-2.06)$ & $1.27(1.11-1.47)$ & $0.89(0.64-1.24)$ \\
\hline $\begin{array}{l}\text { Severe upper respiratory } \\
\text { infection }\end{array}$ & $0.51(0.06-4.21)$ & $1.20(1.05-1.37)$ & $1.33(0.95-1.85)$ \\
\hline \multicolumn{4}{|l|}{ Allergy } \\
\hline Any & $2.31(0.55-9.66)$ & $1.26(1.12-1.43)$ & $\mathrm{I} .14(0.83-\mathrm{I} .57)$ \\
\hline Respiratory & NA 2 & $1.14(0.92-1.42)$ & $1.32(0.78-2.22)$ \\
\hline
\end{tabular}

I Logistic regression analysis: adjusted for the core covariates, preterm delivery and low birth weight.

2 Estimate not available due to small number of exposed cases.

AK conducted the statistical analyses and contributed to the interpretation of the results and writing of the paper. BK participated in the planning of the study and supervision of the data collection, and contributed to the writing of the paper. SK and LP participated in the planning of the study and supervision of the data collection. JS designed and led the study and contributed to the interpretation of the results and writing of the paper. All authors read and approved the final manuscript.

\section{Acknowledgements}

This study was supported by a World Bank loan to the Russian Federation and administered under the environmental epidemiology component of the Centre for Preparation and Implementation of International Projects on Technical Assistance, managed by Vladislav Furman, PhD, with assistance from Victor Kislitsin, PhD, and Natalia Lebedeva, MD, DSc. Analyses were partially supported by the National Institute of Environmental Health Sciences (NIEHS) Center for Environmental Health at the Harvard School of Public Health (grant ES000002); JJ was also supported by The Yrjö Jahnsson Foundation.

\section{References}

I. Kramer MS: Determinants of low birth weight: methodological assessment and meta-analysis. Bulletin of the World Health Organization 1987, 65:663-737.

2. Stick SM, Burton PR, Gurrin L, Sly PD, LeSouef PN: Effects of maternal smoking during pregnancy and a family history of asthma on respiratory function in newborn infants. Lancet 1996, 348:1060-1064.
3. Lødrup Carlsen KC, Jaakkola JJK, Nafstad P, Carlsen KH: In utero exposure to cigarette smoking influences lung function at birth. Eur Respir J 1997, 10:1774-1779.

4. Hoo AF, Henschen M, Dezateux C, Costeloe K, Stocks J: Respiratory function among preterm infants whose mother smoked during pregnancy. Am J Respir Crit Care Med 1998, 158:700-705.

5. Milner AD, Marsh MJ, Ingram DM, Fox GF, Susiva C: Effects of smoking in pregnancy and neonatal lung function. Arch Dis Child Fetal Neonatal Ed 1999, 80:F8-14.

6. Hanrahan JP, Tager IB, Segal MR, Tosteson TD, Castile RCT, Van Vunakis H, Weiss ST, Speizer FE: The effect of maternal smoking during pregnancy on early infant lung function. Am Rev Respir Dis 1992, I45: I I29-III35.

7. Young S, Le Souef PN, Geelhoed GC, Stick STM, Chir B, Turner KJ, Landau LI: The influence of a family history of asthma and parental smoking on airway responsiveness in early infancy. N Engl | Med |99|, 324: I|68-||173.

8. Jaakkola JJK, Jaakkola MS: Effects of environmental tobacco smoke on the respiratory health of children. Scand J Work Environ Health 2002, 28(Suppl 2):7|-83.

9. Jaakkola JJK, Gissler M: Maternal smoking in pregnancy, fetal development, and childhood asthma. Am J Public Health 2004, 94:136-140.

10. Gilliland FD, Li YF, Peters JM: Effects of maternal smoking during pregnancy and environmental tobacco smoke on asthma and wheezing in children. Am J Respir Crit Care Med 200I, 163:429-36.

II. Cunningham J, O'Connor GT, Dockery DW, Speizer FE: Environmental tobacco smoke, wheezing, and asthma in children in 24 communities. Am J Respir Crit Care Med 1996, I 53:2 I 8-224.

12. Lux AL, Henderson AJ, Pocock SJ, the ALSPAC Study Team: Wheezing associated with prenatal tobacco smoke exposure: a procpective, longitudinal study. Arch Dis Child 2000, 83:307-12.

13. Jaakkola JJ, Cherniack M, Spengler JD, Ozkaynak H, Wojtyniak B, Egorov A, et al:: Use of health information systems in the Russian Federation in the assessment of environmental health effects. Environ Health Perspect 2000, 108:589-594. 
14. Ferris BG: Epidemiology Standardization Project (American Thoracic Society). Am Rev Respir Dis 1978, I I8(6 pt 2): I-I20.

15. Jaakkola JJK, Jaakkola N, Ruotsalainen R: Home dampness and molds as determinants of respiratory symptoms and asthma in pre-school children. J Expo Anal Environ Epidemiol I993, 3(Suppl I): $129-42$

16. Privalova LI, Katsnelson BA, Kuzmin SV, Nikonov BI, Gurvich VB, Kosheleva AA, Malykh OL, Voronin SA: Environmental Epidemiology: Principles, Methods, Applications. Ekaterinburg: Medical Research Center for Prophylaxis; 2003.

17. Tager IB: Smoking and childhood asthma-where do we stand? Am J Respir Crit Care Med I998, I 58:349-35 I.

18. Strachan DP, Cook DG: Health effects of passive smoking. 5. Parental smoking and allergic sensitisation in children. Tho$\operatorname{rax}$ 1998, 53: II7-123.

19. Søyseth V, Kongerud J, Boe J: Postnatal maternal smoking increases the prevalence of asthma but not of bronchial hyperresponsiveness or atopy in their children. Chest 1995, 107:389-394.

Publish with Bio Med Central and every scientist can read your work free of charge

"BioMed Central will be the most significant development for disseminating the results of biomedical research in our lifetime. "

Sir Paul Nurse, Cancer Research UK

Your research papers will be:

- available free of charge to the entire biomedical community

- peer reviewed and published immediately upon acceptance

- cited in PubMed and archived on PubMed Central

- yours - you keep the copyright

Submit your manuscript here:

http://www.biomedcentral.com/info/publishing_adv.asp 